\title{
Socioeconomic and Demographic Characteristics of Children Under Five Years of Age Suffering from Stunting in Magelang Regency, Indonesia
}

\author{
Sri Rum Giyarsih, Ratih Fitria Putri, Maulana Malik Sebdo Aji, Yuyun Arining Jayanti, \\ Fauzi Darmawan, Darto Wahidin \\ Universitas Gadjah Mada, Yogyakarta, Indonesia
}

Corresponding Author: Sri Rum Giyarsih (email: srirum@ugm.ac.id)

\begin{abstract}
This study is set out to examine the socioeconomic and demographic characteristics of stunted children under five years of age in Magelang Regency, Central Java Province. Indonesia. It used questionnaire surveys (structured interviews) to collect data on 266 heads of households with stunted children under-five that had been selected using a tiered sampling method, then analyzed the data in the SPPS program. Also, in-depth interviews were conducted with informants from these households and staff of community health center, Health Office, Social Office, and Regional Development Planning Agency (BAPPEDA), and the resulting data were processed and analyzed through the stages of data reduction, data presentation, conclusion withdrawal, and verification. The quantitative data were tested for validity using the statistical procedures provided in the SPSS program, while the qualitative data were examined for their reliability by the triangulation method. The results showed that the majority of stunted children under-five in the regency had normal birth weight and length, received a complete series of immunization, and were breastfed. Furthermore, about one-third of the mothers were employed, showing that many of the families observed are less stable economically. This study also found that parents still lacked the knowledge to recognize stunting in their children, about 80 percent of which did not realize that their children experienced impaired growth and development. Another finding is that government programs have reached 50 percent of families with stunted children under-five.
\end{abstract}

Keywords: stunting; immunization; breastfeeding; children under-five; Magelang Regency

\section{Introduction}

Health is an essential aspect of national development, especially the health of the children (TNP2K, 2017; TNP2K, 2018; WHO, 2018) in which the future of a nation lies (BAPPENAS, 2011). In Indonesia, one of the health problems that has long been under the spotlight is stunting (Ministry of Health,
2017 ; 2018a; 2018b). Stunting is chronic malnutrition caused by a lack of nutritional intake for a long time, causing growth problems that are manifested in shorter (stunted) physical feature than the standard height of children at the same age (Jahari \& Abunain, 1986; De Onis \& Branca, 2016; Aryastami and Tarigan, 2017). 
Due to the shorter feature, it is often believed as a merely genetic or hereditary condition so that many people do not correlate it with health issues (Hidayati et al., 2010; Kurniawati, 2017; Lalo \& Tahu, 2018). It is, however, attributed to low energy intake, infectious diseases, low maternal education, low protein intake, nonexclusive breastfeeding, low education of the father, and working mothers; also, it is even more prevalent in male children under-five than their female counterparts (Ni'mah \& Nadhiroh, 2015; Rahayu, 2015; Nusa \& Kupang, 2016; Rilyani \& Trismiyana, 2016; Mugianti et al., 2018)infectious diseases of $(80.6 \%$.

Stunting is in need of an immediate solution, considering that Indonesia will soon enter a demographic bonus era (BAPPENAS, 2017). Demographic bonus occurs when the population of productive age is higher in number than the non-productive age. Countries must prepare themselves with quality human resources to be able to make use of this era optimally. If not handled immediately, poor quality of human resources will turn demographic bonus, which is predicted to increase economic growth, into a 'window of disaster' as the workforce will hamper rather than boost the development.

Data released by the United Nations Children's Fund (2006) shows that the prevalence of stunted children under-five in Indonesia was 36.4 percent in 2017, the second-highest in ASEAN. Basic Health Research (Riskesdas) confirms that this figure had dropped from 37.2 percent in 2013 to 30.8 percent in 2018 (Ministry of Health, 2018a). Nevertheless, it is still above the threshold set by the $\mathrm{WHO}$, that is, 20 percent. WHO categorizes prevalence between 20 and less than 30 percent as high and $\geq 30$ percent as very high (WHO, 2018).

In 2018, Jakarta (capital of Indonesia) was the only province in the country where stunting was found in less than 20 percent of the children under-five population (TNP2K, 2017; TNP2K, 2018). Central Java is among one of the provinces that cannot achieve the target set by WHO. Although it is famous for its fairly good quality of human resources and large population size, it remains behind in solving stunting prevalence that is above the national percentage (Government of Central Java Province, 2019; 2020). For these reasons, stunting requires serious attention from the parties involved.

Magelang Regency has the secondhighest prevalence of stunting in Central Java Province. The Nutritional Status Monitoring conducted by the Health Office of the regency revealed that stunting is common in 37.6 percent of the children population. In other words, one in three children suffers from impaired growth (Government of Magelang Regency, 2020).

The high prevalence of stunting in Magelang Regency is contrary to macro performance, such as economic growth and the human development index (HDI). Based on BPS data in 2019, the economy of Magelang Regency grew 5.30 percent, positioning it at $29^{\text {th }}$ rank out of 35 regencies/ cities in Central Java Province. In general, this growth is considered high because it is above the national economic growth which is at the level of 5.02 percent. The good economic growth performance of Magelang Regency is also supported by the fairly good performance of human development. Based on BPS data, the HDI level of Magelang Regency in 2019 was 69.87 . This condition is ranked $24^{\text {th }}$ out of 35 regencies/cities in Central Java Province.

The macro-socioeconomic performance of Magelang Regency is quite good in contrast to the condition of the prevalence of stunting. Several studies have stated that the socioeconomic characteristics of the families of children under-five significantly affect stunting. One of them is a study conducted by Ibrahim and Faramita (2015) who took the research location in Makassar City in 2014. The results showed that variables, such as parental education, income, and parental 
occupation, significantly influenced the incidence of stunting.

The description of stunting prevalence and socioeconomic conditions in Magelang Regency at a macro-level proves that research to determine the socioeconomic and demographic characteristics of families of stunted children under-five in Magelang Regency is important to do. This research has benefits for policy-makers to determine in micro-terms the socioeconomic conditions of families of stunted children under-five in Magelang Regency. This information can be used in terms of quick response actions such as direct assistance to families of stunted children under-five.

\section{Recearch Methods}

Data collection methods used in this study were structured interviews with a questionnaire guide and in-depth interviews. Structured interviews were conducted with the household heads of stunted children under-five. In-depth interviews were conducted with several informants from the households of stunted children under-five, integrated services post (posyandu) cadres, public health center (puskesmas), Health Office (Dinas Kesehatan), Social Office (Dinas Sosial), and Regional Development Planning Agency (BAPPEDA) in Magelang Regency who were selected by purposive sampling method.

The socioeconomic variables that will be studied include the physical condition of stunted children under-five, the economic condition of the stunted children under-five household, and the role of the government. The physical condition of stunted children under-five includes gender, age, height, and weight and length at birth. Household conditions for stunted children underfive include mother's education, mother's activities during pregnancy, parents' income, exclusive breastfeeding, immunization, and efforts to treat stunted children under-five.
The role of the government in this research is the attention given by the government to households with stunted children under-five.

In this study, the sample consisted of households with stunted children underfive. In addition, in-depth interviews were conducted with informants or related parties, namely puskesmas staff, Health Office staff, Social Office staff, and BAPPEDA staff. The selection of informants was based on the fact that these parties are directly related to the handling of stunting problems in the regions, so it is hoped that information about stunted children under-five can be obtained more widely and in-depth.

The number of samples used as respondents was 266 heads of households with stunted children under-five who were selected by the sequential sampling method, namely in the first stage the sub-district that had the highest number of stunted children under-five was selected in Magelang Regency so that Tegalrejo Sub-District was chosen. The second stage is to select seven of the 21 villages in Tegalrejo Sub-District based on the proportion of stunted children under-five. Furthermore, in each of these villages, a sample of stunted children underfive was taken.

The next step was to determine the sample size of households with stunted children under-five. According to Purnomo (2017), the adequate sample size for identifying the proportion of a particular population is as follows.

$$
\mathrm{n}=\frac{\left(\frac{z_{\alpha / 2} \sqrt{\pi_{0}\left(1-\pi_{0}\right)}}{\delta}\right)^{2}}{1+\frac{\left(\frac{z_{\alpha / 2} \sqrt{\pi_{0}\left(1-\pi_{0}\right)}}{\delta}\right)^{2}-1}{N}}
$$

where:

$Z_{\alpha / 2}=1.6$ (normal $z$ value)

$\pi_{0}=0.336$ (proportion of households with stunted children under-five to households with children under-five) 


$$
\begin{aligned}
N=1.192 \text { (total population of households } \\
\quad \text { with stunted children under-five) }
\end{aligned}
$$

Based on this equation, the total sample was 266 households, and this sample size was distributed throughout the seven selected villages using proportional allocation.

Data derived from the questionnaire survey were processed in the SPSS program and analyzed using the descriptive statistical method. Before being used to the target group, the research tool, i.e., questionnaire, was first tested for its validity using a pilot group. The same case applied to the resulting data, which were examined for their statistical validity in the SPSS program.

As for the details collected by in-depth interviews with the selected informants, they were processed and analyzed through the following stages (i.e., data reduction, data presentation, conclusion withdrawal, and verification) and examined using a triangulation method to ensure their reliability.

\section{Results and Discussion}

This study found that in Magelang Regency, children under-five suffering from stunting consisted of 49.9 percent male and 50.1 female, with only 0.2 percent difference between the two (see Table 1). In other terms, the amounts of male and female children in this category are nearly similar, thus contradicting Lalo and Tahu (2018), which found that female children are 0.8 times at risk of experiencing stunting than their male counterparts. Female children have more fat tissue but less muscle tissue than male children. When compared to fat, muscle is more metabolically active so that it will require proportionately higher energy than fat. Therefore, male and female children of the same height and age have different body compositions, and accordingly, their energy and nutritional needs also differ from each other (Riyadi, 2001; Proverawati \& Wati, 2011, Reinhardt \& Fanzo, 2014).

\section{Table 1. Percentage of Stunted Children Under-Five by Sex and Age Group in Magelang Regency in 2020}

\begin{tabular}{crrrr}
\hline \multirow{2}{*}{ Age Groups (months) } & \multicolumn{2}{c}{ Sex (Percent) } & \multicolumn{2}{l}{ Total (Percent) } \\
\hline$(1)$ & Male & \multicolumn{1}{c}{ Female } & $(4)$ \\
$0-12$ & $(2)$ & $(3)$ & 8.94 \\
$13-24$ & 64.95 & 35.05 & 22.03 \\
$25-36$ & 51.46 & 48.54 & 27.83 \\
$>36$ & 40.40 & 59.60 & 41.20 \\
\hline Total & 52.35 & 47.65 & 100.00 \\
\hline
\end{tabular}

Source: Primary Data Analysis, 2020

Table 1 shows that most cases of stunting were found in children of 36 months old and above, while children at the age of 0-12 months had the least case of impaired growth and development. In general, there were more stunted male children underfive than their female counterparts, except for the group of 25-36 months old in which there were more females than males. These findings are parallel with the results of previous studies, such as those of Uliyanti et al. (2017), Pradigdo (2018), and Setyawati \& Vilda (2018). 
Sri Rum Giyarsih, Ratih Fitria Putri, Maulana Malik Sebdo Aji, Yuyun Arining Jayanti, Fauzi Darmawan, Darto Wahidin

Table 2. Percentage of Stunted Children Under-Five by Sex and Height in Magelang Regency in 2020

\begin{tabular}{lcccc}
\hline \multirow{2}{*}{ Height } & \multicolumn{2}{c}{ Sex (\%) } & \multirow{2}{*}{ Total (\%) } \\
\cline { 2 - 4 } & \multicolumn{1}{c}{ Male } & Female & \\
\hline \multirow{3}{*}{$(1)$} & $(2)$ & $(3)$ & $(4)$ \\
Shorter & 48.90 & 51.10 & 62.89 \\
Significantly Shorter & 51.61 & 48.39 & 37.11 \\
\hline Total & 49.91 & 50.09 & 100.00 \\
\hline
\end{tabular}

Source: Primary Data Analysis, 2020

Another research finding is that in Magelang Regency, impaired physical growth and development differentiates children into two categories, shorter and significantly shorter height than expected for children of the same age. The former was more prevalent in females (50.09 percent) than males (49.61 percent), while the latter was more common in males (51.61 percent) than females (48.39 percent). Overall, stunting was manifested more in shorter (62.89 percent) rather than significantly shorter heights (37.11 percent) (see Table 2), which supports the study by Azriful et al. (2018).

Table 3. Percentage of Stunted Children Under-Five by Sex and Birth Weight in Magelang Regency in 2020

\begin{tabular}{lcccc}
\hline \multirow{2}{*}{ Birth Weight } & \multicolumn{2}{c}{ Sex (\%) } & Total (\%) \\
\cline { 2 - 3 } & Male & Female & \\
\hline & $(1)$ & $(2)$ & $(3)$ & $(4)$ \\
$<2.5 \mathrm{Kg}$ & 60.87 & 39.13 & 8.47 \\
$>=2.5 \mathrm{Kg}$ & 48.89 & 51.11 & 91.53 \\
\hline Total & 49.91 & 50.09 & 100.00 \\
\hline
\end{tabular}

Source: Primary Data Analysis, 2020

Table 3 shows the proportions of children under-five who suffered from stunting by sex and birth weight. In males, stunting coincided more with low birth weight, i.e., less than 2.5 $\mathrm{kg}$, and this was $21.74 \%$ more prevalent than in females. Meanwhile, males and females constituted, respectively, 48.89 and 51.11 percent of stunted children with a birth weight of more than $2.5 \mathrm{~kg}$. Overall, there were more stunted children with a birth weight of equal to or more than $2.5 \mathrm{~kg}$ than the contrary. Although low birth weight is known to affect future linear growth process and normal birth weight is more likely to cause stunting, this is not necessarily true for this research and several previous studies, including Lalo \& Tahu (2018), Aridiyah et al. (2015), and Winowatan et al. (2019). 
Table 4. Percentage of Stunted Children Under-Five by Sex and Birth Length in Magelang Regency in 2020

\begin{tabular}{lcccc}
\hline \multirow{2}{*}{ Length } & \multicolumn{2}{c}{ Sex (\%) } & \multirow{2}{*}{ Total (\%) } \\
\cline { 2 - 4 } & $(1)$ & Male & Female & \\
\hline \multirow{3}{*}{$<45 \mathrm{Cm}$} & $(2)$ & $(3)$ & $(4)$ \\
$>=45 \mathrm{Cm}$ & 48.18 & 51.82 & 10.13 \\
\hline Total & 50.10 & 49.90 & 89.87 \\
\hline
\end{tabular}

Source: Primary Data Analysis, 2020

Table 4 shows that among the stunted children with a birth length of less than $45 \mathrm{~cm}$ (abnormal), there were 48.18 percent males and 51.82 percent females. Meanwhile, the proportions of male and female stunted children with a birth length of equal to or more than $45 \mathrm{~cm}$ (normal) were 50.10 and 49.90 percent, respectively. Overall, stunting was more prevalent in children under-five with normal than abnormal birth length. This finding does not contradict the results of Adianti (2010).

Table 5 presents the proportions of stunted children under-five by breastfeeding. Around 98.8 percent of them were breastfed, while only a small proportion of them (1.2 percent) were never breastfed. This finding is also in line with Paramashanti (2016), Kusumawardani et al. (2017), Kustiani \& Misa
(2018), and Hanum (2019), thus creating an initial overview that the majority of stunted children in the regency were breastfed. However, a study conducted by Monica et al. (2020) showed different results. In their study, children who were not exclusively breastfed were 61 times more likely to be stunted. This shows that there is an anomaly in children under-five who experience stunting in Magelang, where most of the children underfive who experience stunting have actually been breastfed. According to WHO, exclusive breastfeeding is recommended for the first 6 months of life, continued for up to 24 months with additional complementary foods. It is possible that the duration of breastfeeding for stunted children under-five in Magelang is short so that nutritional needs are not met.

\section{Table 5. Percentage of Stunted Children Under-Five by Breastfeeding in Magelang Regency in 2020}

\begin{tabular}{lcc}
\hline & Breastfed & Percentage \\
\hline & $(1)$ & $(2)$ \\
Yes & & 98.8 \\
No & 1.2 \\
\hline Total & & 100.0 \\
\hline
\end{tabular}

Source: Primary Data Analysis, 2020 
Table 6 divides female and male stunted children based on basic immunization into two categories, receiving incomplete immunization and receiving complete immunization. In the first category, there were more females (52.99 percent) than males (47.01 percent), whereas, in the second category, there were fewer females
(49.74 percent) than males (50.26 percent). It can be postulated that children under-five who received an incomplete series of basic immunization were 12.33 percent fewer than those who were given the complete ones (87.67 percent). This finding is consistent with Sutarto et al. (2018) and Utomo (2018).

\section{Table 6. Percentage of Stunted Children Under-Five by Sex and Basic Immunization in Magelang Regency in 2020}

\begin{tabular}{cccc}
\hline \multirow{2}{*}{ Basic Immunization } & \multicolumn{2}{c}{ Sex (\%) } & \multirow{2}{*}{ Total (\%) } \\
\hline \multicolumn{1}{c}{$(1)$} & $(2)$ & Female & $(4)$ \\
Incomplete $(<10$ times $)$ & 47.01 & 52.99 & 12.33 \\
Complete $(>=10$ times $)$ & 50.26 & 49.74 & 87.67 \\
\hline Total & 49.86 & 50.14 & 100.00 \\
\hline
\end{tabular}

Source: Primary Data Analysis, 2020

Based on Table 6, receiving complete basic immunization does not entirely guarantee that children will not suffer from stunting. In line with Aridiyah (2015), this study found that immunization or vaccination is not associated with cases of stunting in children under-five, both in rural and urban areas. Another aspect that determines the benefits and effectiveness of immunization is vaccine quality (i.e., whether or not the vaccines meet the standards). In other word, children under-five who have received complete and incomplete series of immunization have equal possibility to suffer from impaired growth and development

Apartfromhealthcare, the socioeconomic and demographiccharacteristicsoftheparents can lead to stunting. The characteristics in question are maternal education, maternal activities during pregnancy, maternal age at pregnancy, and income of the parents. The following discussion will focus on these variables based on the survey findings in 2020.

Educational attainment is an indicator of a person's knowledge: the higher the educational level of the parents, the more comprehensive the knowledge they have. The education of mothers requires particular attention because they have an enormous influence on children's growth and development. Mugianti et al. (2018) have confirmed that low maternal education can indicate insufficient knowledge of how and to what extent impaired growth manifests in children and is thereby considered as a factor of stunting. 


\section{Table 7. Percentage of Mothers with Stunted Children Under-Five by Educational Levels in Magelang Regency in 2020}

\begin{tabular}{lc}
\hline \multicolumn{1}{c}{ Educational Levels } & Percentage \\
\hline \multicolumn{1}{c}{$(1)$} & $(2)$ \\
\hline Did not complete elementary school & 0.47 \\
Elementary Schools (SD/equivalent) & 25.19 \\
Lower Secondary Education (SMP/equivalent) & 35.07 \\
Upper Secondary Education (SMA/equivalent) & 29.29 \\
Higher Education & 9.98 \\
\hline Total & 100.00 \\
\hline
\end{tabular}

Source: Primary Data Analysis, 2020

Based on Table 7, the educational level of more than 60 percent of mothers with stunted children in the Magelang Regency was Lower Secondary Education and below. Only 39 percent of them completed their Upper Secondary Education and Higher Education. Overall, mothers with stunted children under-five had categorically low educational attainment and, therefore, had a rudimentary knowledge of child development. Kurniawati (2017) also found how maternal knowledge is closely related to feeding and parenting styles. Similarly, other studies by Sulatri (2012) and Lestari (2018) affirmed that the educational level of the mothers positively correlates with the nutritional status of children; mothers with low educational levels tend to have undernourished children. Although breastfeeding and complete immunization have been carried out, it does not rule out the possibility of children experiencing stunting because another factor that plays a role is the mother's knowledge. Children also need nutritional intake from other food sources. This is more likely to be fulfilled in children with high maternal education because the mother's knowledge about child growth is better.

According to birth order, up to 40 percent of stunted children under-five were second-born, one-third were first-born, and 19 percent were third-born. Furthermore, during pregnancies, just over half of their mothers were unemployed and stay-athome (homemaker), while 37.45 percent of them were employed (Table 8). Mugiyanti et al. (2018) affirmed that working mothers are a contributing factor in stunting among children under-five. Mothers who work during pregnancy are more at risk of having less health care because of their activities while working in the public sector. Expectant women need adequate rest for healthier growth and development of the fetus. 
Sri Rum Giyarsih, Ratih Fitria Putri, Maulana Malik Sebdo Aji, Yuyun Arining Jayanti, Fauzi Darmawan, Darto Wahidin

Table 8. Percentage of Mothers with Stunted Children Under-Five by Economic Activities during Pregnancy in Magelang Regency in 2020

\begin{tabular}{lcc}
\hline & Activities & Percentage \\
\hline & $(1)$ & $(2)$ \\
\hline Unemployed & & 4.87 \\
Homemaker & & 57.02 \\
Employed & & 37.45 \\
Others & 0.66 \\
\hline Total & & 100.00 \\
\hline
\end{tabular}

Source: Primary Data Analysis, 2020

On the one hand, this finding supports Sulatri (2012), which asserted that stunting is more common in families with mothers who do not work. On the other hand, it contradicts the finding of Pradigdo et al. (2018) that there is no relationship between working mothers and child stunting. In other words, there is no guarantee that children with stay-at-home mothers are less at-risk of experiencing stunting than those with working mothers, although other factors are contributing to this risk.

Table 9 shows the percentages of mothers by childbearing age. The majority of mothers with stunted children (79.76 percent) were pregnant at the age of 20-35 years. About 12.63 percent of them were pregnant at the age of more than 35 years old, and 7.61 percent of them were pregnant at the age of younger than 20 years.

Table 9. Percentage of Mothers with Stunted Children by Childbearing Age in Magelang Regency in 2010

\begin{tabular}{cc}
\hline Age & Percentage \\
\hline$(1)$ & $(2)$ \\
\hline$<20$ & 7.61 \\
$20-35$ & 79.76 \\
$>35$ & 12.63 \\
\hline Total & 100.00 \\
\hline
\end{tabular}

Source: Primary Data Analysis, 2020

According to Notoatmodjo (2013), pregnancy at younger ( $<20$ years old) and older age (>35 years old) has substantial risks of obstetric complications compared with at the age of 20-35 years. In this context, younger women are not physically and mentally ready for pregnancy due to the tendency of unstable emotional nature and living conditions, as well as insufficient knowledge of pregnancy or childbirth. Meanwhile, at an older age ( $\geq 35$ years old), women are no longer physically ideal for gestation.

Table 10 classifies the parents of stunted children under-five into either of the two categories: receiving income below or above the Minimum Wage of Magelang Regency, i.e., IDR1,742,000 (Government of Central 
Java Province, 2017). The percentage of the parents who earned income above the Minimum Wage (55.10 percent) was higher than the opposite (44.90 percent). From an economic perspective, most parents with stunted children under-five were in a fairly good state. This finding, however, contradicts Hidayati et al. (2010), which associated incomes of below the Minimum Wage with cases of stunted children under-five in Surakarta City (also a region in Central Java Province). It is because of differences in the physical and socioeconomic characteristics of the research areas. Furthermore, Ni'mah \& Nadhiroh (2015) also found that low income contributes to stunting issues in children.

\section{Table 10. Percentage of Parents with Stunted Children by Incomes in Magelang Regency in $\mathbf{2 0 2 0}$}

\begin{tabular}{lc}
\hline \multicolumn{1}{c}{ Income } & Percentage \\
\hline \multicolumn{1}{c}{$(1)$} & $(2)$ \\
$<$ minimum wage of the regency & 44.90 \\
$\geq$ minimum wage of the regency & 55.10 \\
\hline Total & 100.00 \\
\hline
\end{tabular}

Source: Primary Data Analysis, 2020

For self-sufficient families, parents are assumed to have the resources to meet their primary needs and more and fulfill the nutritional need of their children. In most countries, childbearing requires many funds because expectant women need adequate nutritional intake to prevent stunting issues as early as possible (Chopra, 2003; Wamani et al., 2006). When this is not fulfilled, it is highly likely that the low nutritional intake of the mothers harms the growth and development of the children in the future. However, the research data showed that parents of stunted children earned income that was higher than the Minimum Wage. For this reason, stunting must coincide with other factors other than the categorically self-sufficient parents.

Chronic malnutrition in children is the leading factor of stunting (Kustiani and Misa, 2018). It refers to a condition where a child is malnourished for a long time due to, first, parent's rudimentary knowledge of nutrition and, second, eating difficulties, as evident from the interview excerpt below:
"My son doesn't want to eat, even [when I have provided him] with different types of food. That's why he is thin." (in-depth interview with Informant 3 on July 5, 2020)

Figure 1 demonstrates mothers' perception on child growth in the Magelang Regency. The majority of the respondents (86 percent) thought that their children had normal growth, while the minority (14 percent) admitted that their children did not grow up like other children of the same age. This illustrates that many parents of stunted children under-five in the study area are less attentive to the growth and development of their children. Meanwhile, two possibilities underlie the low percentage of mothers who admitted to their children's impaired growth, namely poor knowledge of stunting and fear of public shaming if their children were to be labeled as stunted. A mother of stunted children in Kebon Agung revealed that she was often the object of public shaming by the neighbors, as evident from the interview excerpt below: 
"I sometimes feel embarrassed because my neighbors keep teasing me, saying that my child is so thin. They think that my child is malnourished, but he is actually healthy and eats a lot." (in-depth interview with Informant 1 on July 5, 2020)
According to the public perception in Kebon Agung, stunting is a condition stemming from malnutrition, and it can be analogous to the inability of the parents to fulfill their children's nutrition. This is the reason why many parents were reluctant to admit that their children fell into the category of stunted.

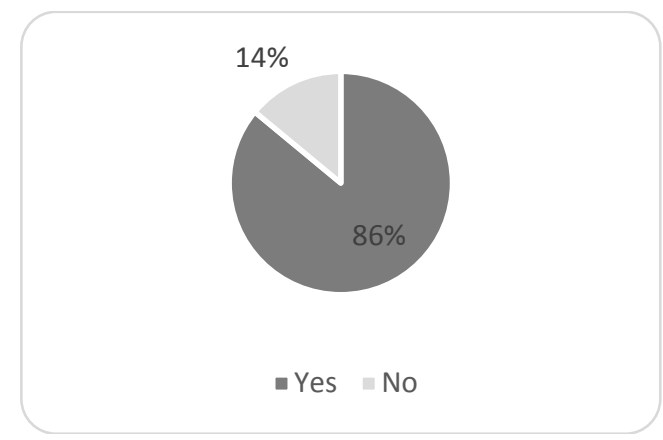

Source: Primary Data Analysis, 2020

Figure 1. Percentage of Mothers with Stunted Children Under-Five by Perceptions of Child Growth in Magelang Regency in 2020

The handling of stunted children in the Magelang Regency is not optimal because the parents lack the knowledge of child growth. As seen in Figure 2, even about 28 percent of the 14 mothers who recognized the impaired growth of their children did not initiate any specific treatments. Meanwhile, the other 70 percent sought assistance from modern health services, and the remaining 2 percent administered traditional medicines (Figure 2).

The government, through the posyandu, routinely organizes public dissemination and discussion on stunting. Families with children under-five are invited to the house of the village head to receive counseling once a month. The government also provides nutritious food for children, such as bread and fruits, as confirmed by the interview excerpt below:

"The neighborhood health center organizes a monthly activity, on the tenth day of every month in this village. Yes, counseling is often held at the health center as well, and every time there is some food, such as cookies and fruits, for the children." (in-depth interview Informant 2 on July 5, 2020) 


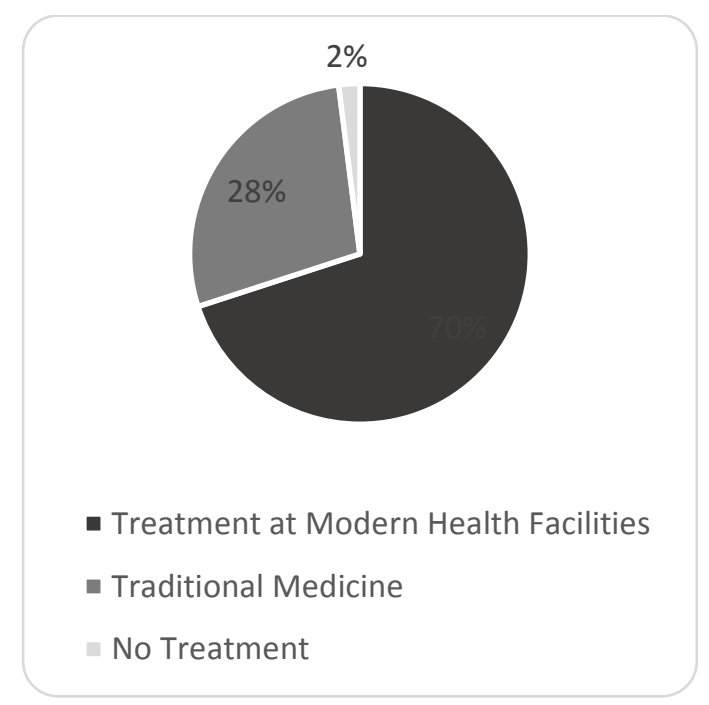

Source: Primary Data Analysis, 2020

Figure 2. Percentage of Parents with Stunted Children by Curative Treatments in Magelang Regency in 2020

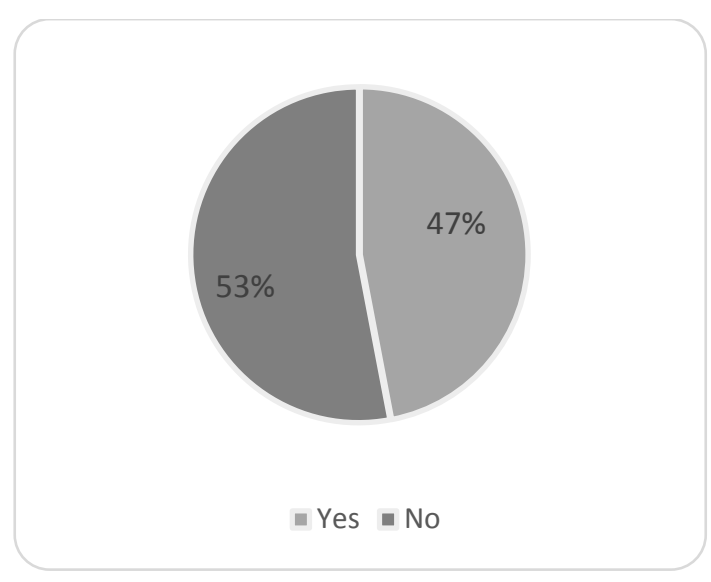

Source: Primary Data Analysis, 2020

Figure 3. Percentage of Households with Stunted Children Under-Five by Governmental Interventions in Magelang Regency in 2020

Figure 3 shows that 53 percent of households with stunted children underfive felt the assistance provided by the government. Meanwhile, the remaining 47 percent believed that no government programs were focusing on addressing stunting issues. These results indicate that nearly half of these households do not gain adequate information from the dissemination of public information on stunting.

\section{Conclusion}

The majority of children under-five suffering from stunting in Magelang Regency have normal birth weight and length and 
have also received complete immunization; also, nearly all of them are breastfed. There is no tendency for stunting to occur in male or female children because the proportion of stunting by sex is almost the same, i.e., 49.95\%:50.05\%. However, in the 0-12 month age group, male children under-five have a higher stunting rate than female children under-five, i.e. $65 \%: 35 \%$. This gap continues to decrease with the increasing age of children. This shows that the majority of toddlers who have been fully immunized and received the majority of breast milk have an influence on the development of male babies.

The condition of parents, namely mothers of stunting toddlers in Magelang Regency, is not good enough. The majority of mothers are employed with Lower Secondary Education and below. Almost half of the parents of stunted children have incomes below the Minimum Wage. Awareness of modern medicine for parents of stunted children under-five is not yet 100 percent. There is still 30 percent of parents who have not prioritized modern medicine.

The current condition allows the local government to focus on improving the condition of parents of stunted children under-five. The improvements start from income, knowledge, and education so that stunted children under-five get additional proper nutrition. In addition, counseling to prioritize modern medicine is also important.

\section{Acknowledgment}

The authors would like to thank the households of stunted children under-five for their willingness to be the interview respondents during the primary data collection in this research.

\section{References}

Adianti. 2010. Faktor Determinan "Stunting" pada Anak Usia 24-59 Bulan di Indonesia. Master Thesis. Institut Pertanian Bogor. Tidak dipublikasikan.

Aridiyah, F., N. Rohmawati., \& M. Ririanty. 2015. Faktor Yang Memengaruhi Stunting pada Balita di Pedesaan dan Perkotaan. e-Jurnal Pustaka Kesehatan 3(1), 11-25

Aryastami, N.K., \& I. Tarigan. 2017. Kajian Kebijakan dan Penanggulangan Masalah Gizi Stunting di Indonesia. Buletin Penelitian Kesehatan 45 (4), 233-240.

Azriful, A., E. Bujawati, E., H. Habibi., S. Aeni, S., \& Y. Yusdarif. 2018. Determinan Kejadian Stunting Pada Balita Usia 24-59 Bulan di Kelurahan Rangas Kecamatan Banggae Kabupaten Majene. Al-sihah: The Public Health Science Journal 10(2), 192-203.

BAPPENAS (National Development Planning Agency). (2011). Rencana Aksi Nasional Pangan dan Gizi 2011-2015. Jakarta: BAPPENAS.

Chopra, M. 2003. Risk Factors for Undernutrition of Young Children in A Rural Area of South Africa. Public Health Nutr 6, 645-52.

De Onis, M., \& F. Branca. 2016. Childhood Stunting: A global Perspective. Maternal and Child Nutrition, 12: 12-26. https://doi. org/10.1111/men.12231.

Government of Magelang Regency. 2020. (internet) <https://magelang.go.id/> (retrieved on February 26, 2020 at 21.26 WIB).

Government of Central Java Province. 2017. Keputusan Gubernur Central Java Nomor 560/94 Tahun 2017. Retrieved from http:// www.semarangkab.go.id/utama/images/ stories/data/UMK-Jateng-2018.pdf

Government of Central Java Province. 2019. Peraturan Gubernur Central Java (Pergub) Nomor 34 Tahun 2019 Tentang Percepatan Pencegahan Stunting. 2020. (internet) <https://jdih.jatengprov. 
go.id/inventariasi-hukum/view/no-34tahun-2019-7> (retrieved on February 26,2020 at 21.26 WIB).

Government of Central Java Province. (2020). (internet) <https://jatengprov.go.id/> (retrieved on February 26, 2020 at 21.24 WIB).

Hanum, N. H. 2019. Hubungan Tinggi Badan Ibu dan Riwayat Pemberian MP-ASI dengan Kejadian Stunting pada Balita Usia 24-59 Bulan. Amerta Nutrition 3(2), 78-84.

Hidayati, L., H. Hadi., \& A. Kumara. 2010. Kekurangan Energi dan Zat Gizi Merupakan Faktor Risiko Kejadian Stunted Pada Anak Usia 1-3 Tahun yang Tinggal di Wilayah Kumuh Perkotaan Surakarta. Kesehatan 3(1), 89-104.

Ibrahim, I. A., \& Faramita, R. 2015. Hubungan faktor sosial ekonomi keluarga dengan kejadian stunting anak usia 24-59 bulan di wilayah kerja puskesmas Barombong kota Makassar tahun 2014. Al-Sihah : Public Health Science Journal, 7(1), 63-75. http://103.55.216.55/index.php/ Al-Sihah/article/view/1978.

Jahari, A.B., \& D. Abunain. 1986. Perbandingan Validitas Beberapa Indeks Antropometri untuk Pemantauan Status Gizi Anak Balita. Gizi Indonesia 11 (2), 15-21.

Kurniawati, T. 2017. Langkah-Langkah Penentuan Sebab Terjadinya Stunting pada Anak. Pedagogi: Jurnal Anak Usia Dini Dan Pendidikan Anak Usia Dini 3(1), 58-69.

Kustiani, A., \& A.P. Misa. 2018. Perubahan Pengetahuan, Sikap, Dan Perilaku Ibu Dalam Pemberian MP-ASI Anak Usia 6-24 Bulan Pada Intervensi Penyuluhan Gizi Di Lubuk Buaya Kota Padang. Jurnal Kesehatan Perintis (Perintis's Health Journal), 5 (1), 51-57. https://doi. org/10.33653/jkp.v5i1.94

Kusumawardhani, I., I.M.A. Gunawan, \& I. Aritonang. 2017. ASI Eksklusif, Panjang Badan Lahir, Berat Badan
Lahir Rendah Sebagai Faktor Risiko Terjadinya Stunting Pada Anak Usia 6-24 Bulan Di Puskesmas Lendah II Kulon Progo (Doctoral dissertation, Poltekkes Kemenkes Yogyakarta). Tidak dipublikasikan.

Lalo, E., \& S.K. Tahu. 2018. Faktor-Faktor yang Berhubungan dengan Kejadian Stunting pada Balita di Wilayah Kerj Unit Pelayanan Terpadu (UPT) Puskesmas Oebobo Kupang. Jurnal CHMK Midwifery Scientific 2 (3), 9-19.

Lestari, W., K. Lusi., \& P.Astridya. 2018. Stunting: Studi Konstruksi Sosial Masyarakat Perdesaan dan Perkotaan Terkait Gizi dan Pola Pengasuhan Balita di Kabupaten Jember. Aspirasi: Jurnal Masalah-Masalah Sosial 9(1), 17-33.

Ministry of Health of the Republic Indonesia. 2009. Buku Saku Gizi. Kapankan Masalah Ini Berakhir? Jakarta: Kemenkes RI. Saku Pemantauan Status Gizi Tahun 2017. Jakarta: Kemenkes RI.

Stunting. Kementerian Kesehatan Republik Indonesia, 301(5), 1163-1178.

Mugianti, S., A.Mulyadi., A.K.Anam., \& Z.L.Naja. 2018. Faktor Penyebab Anak Stunting Usia 25-60 Bulan di Kecamatan Sukorejo Kota Blitar. Jurnal Ners Dan Kebidanan (Journal of Ners and Midwifery), 5(3) 268-278. https://doi. org/10.26699/jnk.v5i3.art.p268-278.

Notoatmodjo, S. 2013. Promosi Kesehatan dan Perilaku Kesehatan. Jakarta: Rineka Cipta.

Ni'mah. K., \& S.R. Nadhiroh. 2015. Faktor yang Berhubungan dengan Kejadian Stunting Pada Balita. Jurnal Media Gizi Indonesia 10 (1), 13-19.

Nusa, U., \& C. Kupang. 2016. Faktor Penentu Stunting Anak Balita Pada Berbagai Zona Ekosistem Di Kabupaten Kupang. Jurnal Gizi Dan Pangan 11(1: 9-18. https://doi. org/10.25182/jgp.2016.11.1.\%p 
Sri Rum Giyarsih, Ratih Fitria Putri, Maulana Malik Sebdo Aji, Yuyun Arining Jayanti, Fauzi Darmawan, Darto Wahidin

Paramashanti, B. A., H. Hadi, \& I.M.A. Gunawan. 2016. Pemberian ASI Eksklusif Tidak Berhubungan dengan Stunting pada Anak Usia 6-23 Bulan di Indonesia. Jurnal Gizi dan Dietetik Indonesia (Indonesian Journal of Nutrition and Dietetics), 3(3), 162-174.

Pradigdo, E. 2018. Faktor Yang Memengaruhi Stunting Pada Balita Usia 24-59 Bulan Di Puskesmas Cepu Kabupaten Blora. Jurnal Kesehatan Masyarakat (e-Journal), 6(5), 454-461.

Proverawati, A., \& E.K. Wati, EK. 2011. IImu Gizi untuk Keperawatan \& Gizi Kesehatan. Yogyakarta: Penerbit Muha Medika.

Purnomo, R.A. 2017. Menulis Penelitian. Ponorogo: UNMUH Ponorogo Press. http://eprints.umpo.ac.id/2852/2/ Menulis\%20Penelitian.pdf.

Rahayu, A. 2015. Riwayat Berat Badan Lahir dengan Kejadian Stunting pada Anak Usia di Bawah Dua Tahun. Jurnal Kesehatan Masyarakat 10 (2), 67-73.

Reinhardt, K., \& J. Fanzo. 2014. Addressing Chronic Malnutrition through Multisectoral, Sustainable Approaches: A Review of Causes and Consequences. Frontiers in Nutrition, 1(August), 120121. https://doi.org/10.1159/000441823.

Riyadi, H. 2001. Metode Penilaian Status Gizi secara Antropometri. Jurusan Gizi Masyarakat dan Sumberdaya Keluarga. Bogor: Fakultas Pertanian, Institut Pertanian Bogor.

Rilyani \& E. Trismiyana. 2016. Faktor-Faktor yang Berhubungan dengan Kejadian Stunting Pada Balita di Puskesmas Panjang Bandar Lampung Tahun 2018. Jurnal Kesehatan Holistik 10 (03), 105114.

Setyawati., \& A.V. Vilda. 2018. Kajian Stunting Berdasarkan Umur dan Jenis Kelamin di Kota Semarang. Proceeding of The URECOL: 834-838.

Sulatri, D. 2012. Faktor Determinan Kejadian Stunting Pada Anak Usia Sekolah
Di Kecamatan Lubuk Kilangan Kota Padang. Majalah Kedokteran Andalas, 36(1), 39-50.

Sutarto., M. Diana., \& R. Indriyani. 2018. Stunting, Faktor Resiko, dan Pencegahannya. J Agromedicine 5 (1), 540-545.

TNP2K. 2017. Ringkasan 100 Kabupaten/ Kota Prioritas untuk Intervensi Anak Kerdil (Stunting). Jakarta: TNP2KSekretariat Wakil Presiden Republik Indonesia.

------. 2018. Gerakan Nasional Pencegahan Stunting dan Kerjasama Kemitraan Multi Sektor. Jakarta: TNP2K-Sekretariat Wakil Presiden Republik Indonesia.

Uliyanti., D.G. Tamtomo., \& S. Anantanyu. 2017. Faktor yang Berhubungan dengan Kejadian Stunting pada Balita Usia 2459 Bulan. JVK-Jurnal Vokasi Kesehatan 3 (2), 67-77.

United Nations Children's Fund (UNICEF). 2006. Children Living in Poverty: Overwiew of Definition, Measurements and Policy. Division of Policy and Planning. New York: UNICEF.

Utomo, B. S. 2018. Bersama Cegah Stunting. Jakarta: Kementerian Kesehatan Republik Indonesia.

Wamani. H., A.N. Åstrøm., S. Peterson., J.K.Tumwind, \& T. Tylleskär. 2006. Predictors of Poor Anthropometric Status Among Children Under 2 Years of Age in Uganda. Public Health Nutr 6 (9), 320-26.

WHO. 2018. Exclusive breastfeedingfor optimal growth, development, and health of infant. Tersedia di http://www.who.int/ elena/titles/exclusive_breastfeeding/en/. (retrieved on November 01, 2019).

Winowatan, G., N.S. Malonda., \& M.I. Punuh. 2019. Hubungan Antara Berat Badan Lahir Anak Dengan Kejadian Stunting Pada Anak Batita Di Wilayah Kerja Puskesmas Sonder Kabupaten Minahasa. KESMAS, 6(3), 25-41. 